\title{
Remediation of incomplete nitrification and capacity increase of biofilters at different drinking water treatment plants through copper dosing
}

Wagner, Florian Benedikt; Borch Nielsen, Peter; Boe-Hansen, Rasmus; Albrechtsen, Hans-Jørgen

Published in:

Water Research

Link to article, DOI:

10.1016/j.watres.2017.12.061

Publication date:

2018

Document Version

Peer reviewed version

Link back to DTU Orbit

Citation (APA):

Wagner, F. B., Borch Nielsen, P., Boe-Hansen, R., \& Albrechtsen, H-J. (2018). Remediation of incomplete nitrification and capacity increase of biofilters at different drinking water treatment plants through copper dosing. Water Research, 132, 42-51. https://doi.org/10.1016/j.watres.2017.12.061

\section{General rights}

Copyright and moral rights for the publications made accessible in the public portal are retained by the authors and/or other copyright owners and it is a condition of accessing publications that users recognise and abide by the legal requirements associated with these rights.

- Users may download and print one copy of any publication from the public portal for the purpose of private study or research.

- You may not further distribute the material or use it for any profit-making activity or commercial gain

- You may freely distribute the URL identifying the publication in the public portal 


\section{Accepted Manuscript}

Remediation of incomplete nitrification and capacity increase of biofilters at different drinking water treatment plants through copper dosing

Florian B. Wagner, Peter Borch Nielsen, Rasmus Boe-Hansen, Hans-Jørgen Albrechtsen

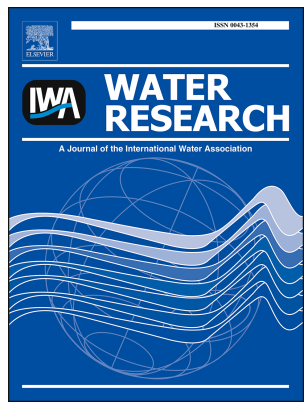

PII: S0043-1354(17)31056-4

DOI: 10.1016/j.watres.2017.12.061

Reference: WR 13459

To appear in: Water Research

Received Date: 16 August 2017

Revised Date: 21 December 2017

Accepted Date: 22 December 2017

Please cite this article as: Wagner, F.B., Nielsen, P.B., Boe-Hansen, R., Albrechtsen, Hans.-Jø., Remediation of incomplete nitrification and capacity increase of biofilters at different drinking water treatment plants through copper dosing, Water Research (2018), doi: 10.1016/j.watres.2017.12.061.

This is a PDF file of an unedited manuscript that has been accepted for publication. As a service to our customers we are providing this early version of the manuscript. The manuscript will undergo copyediting, typesetting, and review of the resulting proof before it is published in its final form. Please note that during the production process errors may be discovered which could affect the content, and all legal disclaimers that apply to the journal pertain. 


\section{Cu dosing to 10 biofilters with different}

raw water, $\mathrm{NH}_{4}{ }^{+}$loadings, filter design \& operation, treatment steps at water works
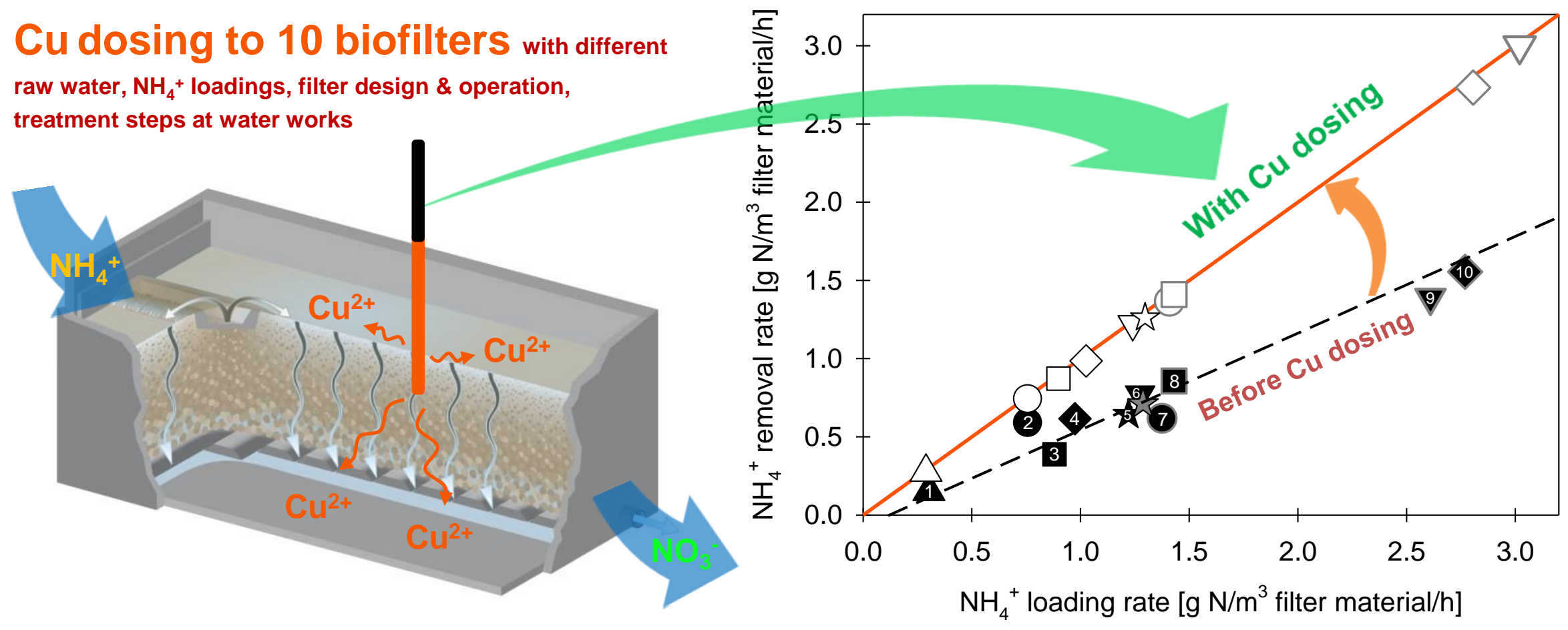


\section{Remediation of incomplete nitrification and capacity increase of biofilters at 2 different drinking water treatment plants through copper dosing}

${ }^{a}$ Department of Environmental Engineering, Technical University of Denmark, Bygningstorvet, Bygning 115, 2800 Kgs. Lyngby,

5 Denmark

${ }^{b}$ Krüger A/S, Gladsaxevej 363, 2860 Sфborg, Denmark

* Corresponding author. Tel.: +45 45251478. E-mail address: fbw@kruger.dk (F.B. Wagner).

${ }^{\mathrm{t}}$ Present address corresponding author: Krüger A/S, Gladsaxevej 363, 2860 Søborg, Denmark

\section{Abstract}

11 Drinking water treatment plants based on groundwater may suffer from incomplete ammonium removal, which deteriorates drinking water quality and constrains water utilities in the operation of their plants. Ammonium is normally removed through nitrification in biological granular media filters, and recent studies have demonstrated that dosing of copper can stimulate the removal of ammonium. Here, we investigated if copper dosing could generically improve ammonium removal of biofilters, at treatment plants with different characteristics. Copper was dosed at $\leq 1.5 \mu \mathrm{g} \mathrm{Cu} / \mathrm{L}$ to biofilters at 10 groundwater treatment plants, all of which had displayed several years of incomplete nitrification. Plants exceeded the Danish national water quality standard of $0.05 \mathrm{mg} \mathrm{NH}{ }_{4}^{+} / \mathrm{L}$ by a factor of 2-12. Within only 2-3 weeks of dosing, ammonium removal rates increased significantly (up to $150 \%$ ). Nitrification was fully established, with ammonium effluent concentrations of $<0.01 \mathrm{mg} \mathrm{NH}_{4}{ }^{+} \mathrm{N} / \mathrm{L}$ at most plants, regardless of the differences in raw water chemistry, ammonium loading rates, filter design and operation, or treatment plant configuration. However, for filters without primary filtration, it took longer time to reach complete ammonium removal than for filters receiving prefiltered water, likely due to sorption of copper 
23 to iron oxides, at plants without prefiltration. With complete ammonium removal, we subjected two plants to

24 short-term loading rate upshifts, to examine the filters' ability to cope with loading rate variations. After 2 months of dosing and an average loading rate of $1.0 \mathrm{~g} \mathrm{NH}_{4}{ }^{+}-\mathrm{N} / \mathrm{m}^{3}$ filter material/h, the loading rate was upshifted by $50 \%$. Yet, a filter managed to completely remove all the influent ammonium, showing that with copper

27 dosing the filter had extra capacity to remove ammonium even beyond its normal loading rates. Depth sampling revealed that the ammonium removal rate of the filter's upper $10 \mathrm{~cm}$ increased more than 7 -fold from 0.67 to $4.90 \mathrm{~g} \mathrm{NH}_{4}{ }^{+}-\mathrm{N} / \mathrm{m}^{3} / \mathrm{h}$, and that nitrite produced from increased ammonium oxidation was completely oxidized further to nitrate. Hence, no problems with nitrite accumulation or breakthrough occurred. Overall, copper dosing generically enhanced nitrification efficiency and allowed a range of quite different plants to meet water quality standards, even at increased loading rates. The capacity increase is highly relevant in practice, as it makes filters more robust towards sudden ammonium loading rate variations.

\section{Keywords}

Ammonium, biological water treatment, copper deficiency, granular media filtration, groundwater, nutrient

37 limitations

\section{Introduction}

40 Ammonium $\left(\mathrm{NH}_{4}^{+}\right)$is often a concern when anoxic groundwater is used for drinking water production.

41 Generally, ammonium is removed biologically during water treatment, through nitrification in rapid granular

42 media filters. The process is mediated by ammonia oxidizing bacteria (Prosser, 1989) or archaea (Martens-

43 Habbena et al., 2009), which oxidize ammonia to nitrite, and nitrite oxidizing bacteria (Prosser, 1989), which

44 oxidize nitrite to nitrate. Recently, complete oxidation of ammonia to nitrate in one organism (comammox) has 
45 been reported (Daims et al., 2015). Presence of nitrifying microorganisms in biological filters treating groundwater is well studied (de Vet et al., 2011; Gülay et al., 2014; Lee et al., 2014; Palomo et al., 2016).

47 Unfortunately, nitrification is sometimes incomplete, leading to ammonium and/or nitrite residues in the treated water. This can cause microbial aftergrowth in distribution systems without disinfection (van der Kooij, 2000), which may cause oxygen depletion, unpleasant taste and odor, and technical problems such as corrosion (Zhang et al., 2009). Furthermore, in systems with chlorine-based disinfection, ammonium can reduce the disinfection efficiency (Zhang et al., 2009). Incomplete nitrification during treatment therefore poses a risk to drinking water quality and safety. Especially for systems without disinfectant residual, such as in Denmark, efficient removal of growth-promoting nutrients to concentrations as low as possible is essential for preventing microbial aftergrowth (Prest et al., 2016; van der Kooij, 2000). Hence, to ensure safe drinking water, a guideline value for ammonium is set at $0.5 \mathrm{mg} \mathrm{NH}_{4}{ }^{+} / \mathrm{L}$ by the EU drinking water directive (European Comission, 1998). Some EU member states enforce stricter guideline values; like Denmark, with $0.05 \mathrm{mg} \mathrm{NH}_{4}{ }^{+} / \mathrm{L}$ for ammonium and $0.01 \mathrm{mg} \mathrm{NO}_{2}{ }^{-} / \mathrm{L}$ for nitrite (Ministry of Environment and Food of Denmark, 2016).

Ammonium is the parameter that challenges Danish water utilities by far the most. Between 2002 and 2013, out of 5,826 analyzes of effluent water at the larger Danish drinking water treatment plants (treating $>350,000 \mathrm{~m}^{3} / \mathrm{y}$ ), $13.2 \%$ exceeded the ammonium guideline value (Danish Nature Agency, 2014, 2012, 2009, 2007). With the legal water quality demand, poor nitrification performance constrains water utilities in the way they operate their treatment plants. As a result, the hydraulic loading rate (i.e. treatment flow) is often decreased until the effluent guideline is met, which means that the utilities have a reduced treatment capacity. Besides the constraints with regards to production capacity, it furthermore leaves no room for buffering sudden (and sometimes unexpected) loading increases (Lee et al., 2014). Problems with incomplete nitrification have been known for long (Stamer and Nielsen, 2005) and expensive and time-consuming experience based approaches are taken to remediate the deficiencies - often without success. 
Recently, we demonstrated that poor nitrification performance could be resolved by dosing of copper as micronutrient to a rapid sand filter (Wagner et al., 2016a). The metal is vital for the enzyme ammonia monooxygenase, responsible for the oxidation of ammonia (Sayavedra-Soto and Arp, 2011). When copper was dosed to the deficient biofilter, ammonium removal activity rapidly increased (Wagner et al., 2016a). Yet, this investigation focused on a single treatment plant, and parameters affecting the availability of copper like e.g. alkalinity (Zhang and Edwards, 2010), pH (Sylva, 1976), and iron load (Benjamin et al., 1996), can vary from plant to plant. It is therefore of great importance to investigate whether these observations (Wagner et al., 2016a) are generic and applicable at different treatment plants with diverse features. With a stimulation of nitrification, the further question arises whether the dosing can increase biofilters' robustness, and thus enable filters to completely nitrify ammonium even under ammonium loading rate upshifts which exceed the normal loading rates.

In light of the problems with poor nitrification performance constraining treatment plant operation, our study had two main aims: (I) to investigate if copper dosing can generically increase ammonium removal efficiency and thereby remediate incomplete nitrification, at various treatment plants with individual features such as different treatment units, filter designs and operation, ammonium loading rates, raw water chemistry, etc., and (II) to elucidate whether the dosing can increase ammonium removal rates further, beyond the ammonium loading rates typical for the filters. Here, we present a comprehensive investigation on the effect of copper dosing on nitrification at 10 full-scale drinking water treatment plants in Denmark.

2. Materials and methods

\subsection{Investigated drinking water treatment plants}

The investigated 10 drinking water treatment plants (DWTPs) are located across Denmark and abstract groundwater from anaerobic aquifers with different raw water chemistry (Table 1). The selected DWTPs all 
91 failed to completely remove the influent ammonium loadings, leaving ammonium residues in the finished water,

92 and they represented a wide range of different characteristics. The main treatment steps at the plants were

93 aeration of groundwater, followed by granular media filtration. Five plants had primary and subsequent

94 secondary filtration; the other five had single filtration only (Table 2). At all DWTPs, filter material was quartz

95 of variable grain size (except for Bakkebølle DWTP, where calcined flint was used). The depth of active layers

96 (assumed active for removal of ammonium) of the filters varied, as did the hydraulic and ammonium loading

97 rates (Table 2).

98

99

100

101

102

103

104

105

106

107

108

109

110

111

112

113

\subsubsection{Investigations with copper dosing}

To characterize nitrification performance prior to copper dosing, samples for ammonium, nitrite, and copper were collected from the filters' influent and effluent water. Then copper dosing to one or more filters at the

DWTPs started. Copper was dosed by different methods: passive dosing with a solid copper structure releasing copper to the water through contact between fluid and solid, active dosing through electrolysis (Albrechtsen et al., 2015), or as liquid solution prepared from $\mathrm{CuSO}_{4}$ (technical grade, VWR chemicals) (Table 2). Whenever a plant was equipped with primary filtration, copper was dosed to a secondary filter. At the onset of copper dosing, ammonium influent and effluent concentrations were analyzed with a 30 minute frequency with an ammonium auto-analyzer (Hach Lange, AMTAX ${ }^{\mathrm{TM}}$ sc) at Nærum (Wagner et al., 2016a), at Langerød, and Glostrup DWTPs, and elsewhere with at least one sampling per week. During the dosing, operational parameters (such as hydraulic loading, etc.) were maintained constant. Effects of the dosing on nitrification were assessed by comparing dosing filters' effluent ammonium concentrations before and during dosing. Additionally, volumetric ammonium removal rates (ARRs) were calculated to compare the filters performance, at the respective volumetric ammonium loading rates (ALRs) (see 2.4 for calculation). Reference filters, which were operated under the same conditions as the dosing filters, but without dosing, were monitored at DWTPs Nærum (Wagner et al., 2016a), Langerød, Glostrup, Holmehave, and Frederiksgade. 


\subsubsection{Ammonium loading rate upshift experiments}

To investigate robustness of ammonium removal during ammonium loading rate upshifts, ALRs were increased above the normal loading rates at DWTPs Glostrup and Holmehave. Prior to the upshifts, normal loading rates were: $1.23 \pm 0.15 \mathrm{~g} \mathrm{NH}_{4}{ }^{+}-\mathrm{N} / \mathrm{m}^{3} / \mathrm{h}$ at Glostrup, during approximately 8 months, and $1.00 \pm 0.09 \mathrm{~g} \mathrm{NH}_{4}{ }^{+}-\mathrm{N} / \mathrm{m}^{3} / \mathrm{h}$ at Holmehave DWTP, during approximately 7 months. Upshifts started when ammonium removal was complete with dosing, under normal ALRs. During upshifts, average ALRs were $1.49 \pm 0.08$ and $1.18 \pm 0.28 \mathrm{~g} \mathrm{NH}_{4}{ }^{+}-$ $\mathrm{N} / \mathrm{m}^{3} / \mathrm{h}$, with peak ALRs as high as 1.85 and $2.05 \mathrm{~g} \mathrm{NH}_{4}{ }^{+}-\mathrm{N} / \mathrm{m}^{3} / \mathrm{h}$, at Glostrup and Holmehave DWTPs.

Ammonium influent concentrations to the filters were relatively stable, so that the loading upshifts were conducted by increasing the filters' hydraulic loading. ARRs at respective ALRs were calculated to compare nitrification performance. Additionally, at Holmehave DWTP, water was collected over depth of the filter with dosing to determine depth specific ammonium and nitrite removal rates.

\subsection{Water sampling}

Filter effluent water was sampled from sampling taps and influent water was sampled from either taps or from the water on top of the filters. Water depth samples of the filter with dosing at Holmehave DWTP was collected through a PTFE tube inside a supporting rigid stainless steel sampling probe, inserted into the filter at an angle of $45^{\circ}$, and extracted from depths of 10, 20, 30, 40, 50, 60, and $75 \mathrm{~cm}$ with a peristaltic pump (Ole Dich, $101 \mathrm{ACR}$ ) at a rate of $25 \mathrm{~mL} \mathrm{~min}^{-1}$. The hydraulic loading rate to the filter was constant during sampling of a complete water depth profile, which was accomplished within $1 \mathrm{~h}$. Depth sampling was always carried out at the same time within a filtration cycle, one day after the filter was backwashed. Water for ammonium and nitrite analyses was immediately filtered through a sterile $0.2 \mu \mathrm{m}$ filter (Sartorius, Minisart ${ }^{\circledR}$ ), stored at $4{ }^{\circ} \mathrm{C}$, and analyzed within $24 \mathrm{~h}$; or frozen at $-20^{\circ} \mathrm{C}$ and analyzed within 2 weeks. Samples for determination of total copper concentration were collected unfiltered into acid washed PTFE vials and immediately acidified with $65 \%$ nitric acid (Merck, Suprapur®) to $\mathrm{pH}<2$, and stored at $4{ }^{\circ} \mathrm{C}$ until analysis. 


\subsection{Analytical methods}

Ammonium and nitrite were determined by colorimetric methods analogous to APHA 4500-NH3-F and APHA 4500-NO2-B (APHA et al., 2005), with quantification limits of 0.01 and $0.002 \mathrm{mg} \mathrm{N} \mathrm{L}^{-1}$. For the ammonium auto-analyzer, the quantification limit was $0.02 \mathrm{mg} \mathrm{NH}_{4}-\mathrm{N} \mathrm{L}^{-1}$. Unless otherwise noted (Table 2), copper concentrations were determined by inductively coupled plasma mass spectrometry (Agilent Technologies, 7700 Series ICP-MS), according to EPA method 6020A (USEPA, 2007), with a detection limit of $0.01 \mu \mathrm{g} \mathrm{Cu} / \mathrm{L}$.

\subsection{Calculation of nitrification performance indicators and operational parameters}

The volumetric Ammonium Loading Rates of the filters were calculated as $A L R=\mathrm{Qc}_{\mathrm{a}, \mathrm{in}} / \mathrm{A} \Delta \mathrm{z}$, where $\mathrm{Q}$ is the filter flow rate, $\mathrm{c}_{\mathrm{a}, \mathrm{in}}$ is the influent concentration of ammonium, $\mathrm{A}$ is the filter cross section area, and $\Delta \mathrm{z}$ is the depth of the active layers of the filters (see Table 2). The volumetric Ammonium Removal Rate was defined as $\mathrm{ARR}=\mathrm{Q}\left(\mathrm{c}_{\mathrm{a}, \mathrm{in}}-\mathrm{c}_{\mathrm{a}, \text { out }}\right) / \mathrm{A} \Delta \mathrm{z}$, where $\mathrm{c}_{\mathrm{a}, \text { out }}$ is the filter effluent concentration of ammonium. From information of water depth profiles at Holmehave DWTP, depth specific volumetric ammonium and nitrite removal rates were calculated and are denoted $\mathrm{ARR}_{\mathrm{ds}}$ and $\mathrm{NRR}_{\mathrm{ds}}$. When referring to $\mathrm{ARR}_{\mathrm{ds}}$ of a specific layer of the filter, $\mathrm{c}_{\mathrm{a}, \text { in }}$ and $c_{a, o u t}$ are the ammonium influent and effluent concentrations to and from this layer. $\Delta \mathrm{z}$ is the thickness of that specific layer (e.g.: for calculating the $\mathrm{ARR}_{\mathrm{ds}}$ of the layer from 10-20 cm depth, $\mathrm{c}_{\mathrm{a}, \mathrm{in}}$ and $\mathrm{c}_{\mathrm{a}, \text { out }}$ are the ammonium concentrations at 10 and $20 \mathrm{~cm}$ depth, respectively, and $\Delta \mathrm{z}$ is $0.1 \mathrm{~m}$ ). The depth specific Nitrite Removal Rate was calculated as $\mathrm{NRR}_{\mathrm{ds}}=\mathrm{Q}\left[\left(\mathrm{c}_{\mathrm{a}, \mathrm{in}}-\mathrm{c}_{\mathrm{a}, \mathrm{out}}\right)+\left(\mathrm{c}_{\mathrm{n}, \mathrm{in}}-\mathrm{c}_{\mathrm{n}, \mathrm{out}}\right)\right] / \mathrm{A} \Delta \mathrm{z}$, where $\mathrm{c}_{\mathrm{n}, \text { in }}$ and $\mathrm{c}_{\mathrm{n}, \mathrm{out}}$ are the nitrite influent and effluent concentrations to and from the respective layer. The unit of the ALR and the $\mathrm{ARR}_{(\mathrm{ds})}$ is $\left[\mathrm{g} \mathrm{NH}_{4}{ }^{+}-\right.$ $\left.\mathrm{N} / \mathrm{m}^{3} / \mathrm{h}\right]$, where $\mathrm{m}^{3}$ refers to volume of filter material. The $\mathrm{NRR}_{\mathrm{ds}}$ has the unit $\left[\mathrm{g} \mathrm{NO}_{2}-\mathrm{N} / \mathrm{m}^{3} / \mathrm{h}\right]$. The filter velocity $[\mathrm{m} / \mathrm{h}]$ was calculated as $\mathrm{u}=\mathrm{Q} / \mathrm{A}$, and the empty bed contact time $[\mathrm{h}]$ was calculated as $\mathrm{EBCT}=$ $(\mathrm{A} \Delta \mathrm{z}) / \mathrm{Q}$. 


\section{Results and discussion}

161

162

\subsection{Characteristics of the investigated treatment plants prior to dosing}

The investigated DWTPs were chosen because they all have long histories of incomplete nitrification (except for Skive DWTP, which was newly started up). The plants have had problems with incomplete ammonium removal for several years (Fig. 1), and numerous attempts to remediate nitrification performance failed. Right before onset of copper dosing, all DWTPs exceeded an ammonium effluent concentration of $0.05 \mathrm{mg} \mathrm{NH}_{4}^{+} / \mathrm{L}$ (expressed as ammonium- $\mathrm{N}: 0.039 \mathrm{mg} \mathrm{NH}_{4}{ }^{+} \mathrm{N} / \mathrm{L}$ ), with filter effluent concentrations from $0.08 \mathrm{mg} \mathrm{NH}{ }_{4}{ }^{+}-\mathrm{N} / \mathrm{L}$ (Skindermarken DWTP) to values as high as $0.49 \mathrm{mg} \mathrm{NH}_{4}{ }^{+} \mathrm{N} / \mathrm{L}$ (Bakkebølle DWTP; Table 2). Copper concentrations were very low in the filter influent at any of the DWTPs, where copper could not be detected with detection limits of $<0.01$ to $<0.04 \mu \mathrm{g} \mathrm{Cu} / \mathrm{L}$ (Table 2).

Besides the low copper influent concentrations, common for all DWTPs, the plants varied substantially regarding site-specific characteristics. If DWTPs shared similarities, e.g. in filter construction, the plants differed in other features such as treatment configuration, empty bed contact times (EBCT) and ammonium loading rates (Table 2) or raw water chemistry (Table 1). The investigated DWTPs were also contrasted in terms of treatment volumes, with smaller plants such as Bakkebølle DWTP treating $0.2 * 10^{6} \mathrm{~m}^{3} / \mathrm{y}$, and the larger Holmehave DWTP treating $3.56 * 10^{6} \mathrm{~m}^{3} / \mathrm{y}$ (Table 2), showing that both smaller and larger facilities struggle. Ammonium influent concentrations to the filters ranged fairly broadly from 0.15 to $1.17 \mathrm{mg} \mathrm{NH}_{4}{ }^{+} \mathrm{N} / \mathrm{L}$, but not extraordinarily high. The investigated plants were diverse, but they all had in common that the nitrification was incomplete.

Filtration rates ranged from 1.07 to $2.80 \mathrm{~m} / \mathrm{h}$, except Mørkeskov DWTP $(6.46 \mathrm{~m} / \mathrm{h})$, and were thus lower than the typical range for many rapid granular media filters of 5-15 m/h (Crittenden et al., 2005). Correspondingly, contact times in the filters were quite high, with 0.27 to $0.73 \mathrm{~h}$ of empty bed contact time (EBCT; Table 2). Despite the long contact times, volumetric ammonium removal rates (ARR) were not high enough to completely remove the influent ammonium loadings (Fig. 2). Filters at Skive DWTP removed $0.10 \mathrm{~g} \mathrm{NH}_{4}{ }^{+} \mathrm{N} / \mathrm{m}^{3} / \mathrm{h}$, 
equivalent to only $33 \%$ of influent ammonium. Before copper dosing, the ARR was highest at Langerød treatment plant at $1.55 \mathrm{~g} \mathrm{NH}_{4}{ }^{+}-\mathrm{N} / \mathrm{m}^{3} / \mathrm{h}$, corresponding to $56 \%$ removal. The ARRs were very low compared to rates as high as $3.4 \mathrm{~g} \mathrm{NH}_{4}{ }^{+}-\mathrm{N} / \mathrm{m}^{3} / \mathrm{h}$ reported for pilot columns with rapid sand filter material treating prefiltered groundwater (Lee et al., 2014), or compared to $4.35 \mathrm{~g} \mathrm{NH}_{4}{ }^{+}-\mathrm{N} / \mathrm{m}^{3} / \mathrm{h}$ for biological GAC filters treating river water (Laurent et al., 2003), and up to $5 \mathrm{~g} \mathrm{NH}_{4}{ }^{+} \mathrm{N} / \mathrm{m}^{3} / \mathrm{h}$ for trickling filters treating groundwater (de Vet et al., 2011), thereby emphasizing the poor nitrification performance of the studied biofilters.

The low filtration rates and low ammonium loading rates at the investigated DWTPs were partly a result of the poor performance. Initially, the filters were designed for higher loading rates, because usually a "worst-case situation" determines the design, where the water quality which requires the most treatment is combined with a situation where the highest possible water flow needs to be treated. Furthermore, some treatment plants were designed with an expectation of an increasing water demand, which was however never realized. At the investigated DWTPs, the actual loading rates were lower than the design, and due to problems with low ammonium removal capacity, operators had decreased the filter flow even further (if ALRs cannot be lowered by switching to a raw water source with lower ammonium concentrations). Filters are generally designed for removal capacities in the range of 2-8 $\mathrm{g} \mathrm{NH}_{4}{ }^{+}-\mathrm{N} / \mathrm{m}^{3}$ filter material/h. At the investigated DWTPs however, the given very low ALRs of 0.30 to $2.8 \mathrm{~g} \mathrm{NH}_{4}{ }^{+}-\mathrm{N} / \mathrm{m}^{3} / \mathrm{h}$ still resulted in incomplete ammonium removal, which accentuates the poor function of the filters before copper dosing. Violations of the nitrite effluent guideline of $0.003 \mathrm{mg} \mathrm{NO}_{2}^{-}-\mathrm{N} / \mathrm{L}$ were much less frequent at the investigated DWTPs (Table 2), probably because the oxidation of ammonia is the rate-limiting step of nitrification (Martens-Habbena et al., 2009). However, at DWTPs Nærum and Mørkeskov, effluent concentrations violated the water quality standard of $0.003 \mathrm{mg} \mathrm{NO}_{2}^{-}-$ $\mathrm{N} / \mathrm{L}$.

\subsection{Generic resolving of insufficient ammonium removal}

Copper dosing stimulated ammonium removal at all investigated DWTPs. Removal rates increased rapidly (Fig. 2), and within approximately 2-3 weeks, most filters removed ammonium to levels lower than the method 
detection limit of $0.01 \mathrm{mg} \mathrm{NH}_{4}{ }^{+} \mathrm{-N} / \mathrm{L}$ (Table 2). Autotrophic nitrifying bacteria have relatively low growth rates and yields (Zhang et al., 2009) compared to heterotrophs, especially at low temperatures of approx. $9{ }^{\circ} \mathrm{C}$, as in this study (Table 1). The time span of 2-3 weeks therefore indicates that the mechanism of stimulation is probably related to growth of ammonia oxidizing microorganisms. This is in agreement with an earlier study, where ammonia oxidizing bacteria grew as a result of the dosing (Wagner et al., 2016b). Continuous dosing resulted in long-term low effluent concentrations (Fig. 1), thereby improving biological stability (van der Kooij, 2000) of the treated water. At Nærum (Wagner et al., 2016a) and Mørkeskov DWTPs, dosing also decreased nitrite effluent concentrations (Table 2). In control filters without copper dosing at Nærum (Wagner et al., 2016a), Langerød, Glostrup, Holmehave, and Frederiksgade DWTPs, nitrification activity was not increased in the investigated period (data not shown). At Glostrup DWTP, initial, passive copper dosing had no effect on the removal, in contrast to Langerød, Bakkebølle and Skindermarken DWTPs, where application of passive dosing was successful. However, after switching the dosing method in Glostrup to active dosing by an electrode, nitrification activity increased (Table 2). With active dosing by electrode, the release of copper is controlled by electrical current and is generally higher compared to passive dosing, where no current is used (Albrechtsen et al., 2015). The fact that the plants Langerød, Bakkebølle and Skindermarken have de-ironing prefiltration, and Glostrup does not, probably also played a role in the successful application of passive dosing at those plants (see also section 3.3).

The hydraulic loading rates at the DWTPs were unchanged when comparing before and after dosing (except for treatment plants Glostrup and Skive, where hydraulic loading rates were increased after dosing); correspondingly, contact times were not increased after dosing (Table 2). Nevertheless, after the onset of dosing, the filters managed to completely remove the ammonium load (Fig. 2), meaning that the removal efficiency was improved by the dosing. ARRs increased until complete removal of ammonium was achieved, where ARRs were equal to the ALRs, as indicated in Fig. 2 by the diagonal 'complete removal' line. Removal rate increased from $26 \%$ at Skindermarken to $150 \%$ at Skive DWTP, with an average increase for all plants of $87 \%$. 
232 Copper dosing concentrations at the DWTPs were $\leq 1.5 \mu \mathrm{g} \mathrm{Cu} / \mathrm{L}$ (Table 2) and were therefore several orders

233 lower than international health-based guidelines for drinking water of $2000 \mu \mathrm{g} \mathrm{Cu} / \mathrm{L}$ (European Comission, 234 1998; WHO, 2011).

235 Nitrification was successfully stimulated by the rather low concentrations of total copper, regardless of very high 236 alkalinity (e.g. $448 \mathrm{mg} \mathrm{HCO}_{3}{ }^{-} / \mathrm{L}$ at Glostrup), which can decrease the concentration of free $\mathrm{Cu}^{2+}$ (Zhang and 237 Edwards, 2010), the available form of copper (Amin et al., 2013). Furthermore, when pH increases from 7 to 8 , 238 the fraction of $\mathrm{Cu}^{2+}$ decreases from approx. 60 to as little as $10 \%$ (Sylva, 1976). Despite a pH generally $>7$ and 239 values as high as 8.2 at Skindermarken and 8.0 at Skive DWTPs, low concentration copper dosing generically 240 remediated nitrification at all poorly functioning systems, regardless of other different site-specific 241 characteristics of the studied DWTPs (Table 2).

242 Some of the DWTPs (e.g. Nærum and Langerød) had nitrification problems since they were renovated (new 243 filter material and replacement of piping at the plants). It should be further studied, to what extend the use of 244 different materials, for example a trend to replace cast iron pipes with stainless steel or plastic pipes, can aggravate 245 trace metal deficiencies.

\section{3.3. Effect on filters with vs. without primary filtration}

247 When copper was dosed to filters receiving prefiltered water, it took less time until ammonium removal was 248 complete (Fig. 3). For DWTPs with primary filter, the full effect was reached after 12 (Langerød) to 20 days 249 (Valbygård), with an average duration of $15 \pm 3$ days. Two-sample t-test ( $\alpha=0.05$ ) showed that for plants 250 without primary filtration, it took significantly longer $(p$-value $=0.004)$ to reach a full effect. The average 251 duration was $53 \%$ higher ( $23 \pm 4$ days), with times ranging from 21 (Holmehave and Mørkeskov) to 30 days 252 (Glostrup). Durations until complete removal were not correlated with the ammonium loadings of the filters $(r=$ $253-0.23$; Fig. 3). Iron influent concentrations in the filters receiving dosing at plants without primary filtration were substantially higher (Table 2). The slower response of the filters without de-ironing pretreatment may be 
explained by sorption of copper to iron oxides (Benjamin et al., 1996), which reduced the availability for the nitrifying microorganisms.

257 We furthermore investigated possible correlations of the effect of dosing (expressed as change in ARR divided 258 by the time to reach the full effect) with other operational parameters. The change in ARR over time was not 259 correlated with parameters such as filter velocity or EBCT, or ammonium influent concentrations. However, as 260 expected, ARR correlated positively with the ALR $(r=0.94)$, meaning that the change in ARR induced by 261 copper dosing was higher when the ALR was higher.

\subsection{Increasing the filter's robustness towards loading rate increases}

To investigate if copper dosing could increase the ammonium removal rate even beyond the normal ALR of a filter, the ALR to the filter at Glostrup DWTP was increased $20 \%$ from a normal average 1.23 to an average ALR of $1.49 \mathrm{~g} \mathrm{NH}_{4}{ }^{+}-\mathrm{N} / \mathrm{m}^{3} / \mathrm{h}$. Short term loading rate upshifts as high as $1.85 \mathrm{~g} \mathrm{NH}_{4}{ }^{+}-\mathrm{N} / \mathrm{m}^{3} / \mathrm{h}$ were conducted. And yet, the filter completely removed the increased loads, showing that with copper dosing the filter had extra capacity to remove ammonium beyond the normal load. For example, an ARR of $1.84 \mathrm{~g} \mathrm{NH}_{4}{ }^{+}-\mathrm{N} / \mathrm{m}^{3} / \mathrm{h}$ was achieved under an ALR of $1.85 \mathrm{~g} \mathrm{NH}_{4}{ }^{+} \mathrm{N} / \mathrm{m}^{3} / \mathrm{h}$, on day 127 (Fig. 4). Such an extra capacity is needed to buffer shifts in loading rate, which is especially relevant because nitrifying biological filters at drinking water treatment plants are frequently subject to such variations. The upshifts can be caused by either a change in ammonium inlet concentrations (Kors et al., 1998), by a changing water flow to be treated (hydraulic load) (Lee et al., 2014), or a combination of both (Lopato et al., 2013). At another site, Holmehave DWTP, ammonium influent concentrations were rather constant at $0.39 \pm 0.01 \mathrm{mg} \mathrm{NH}_{4}{ }^{+} \mathrm{N} / \mathrm{L}$ ( $\mathrm{n}=32$, sampled between April 2014 and

274 October 2015), and the ALR in this experiment was increased by increasing hydraulic loading rates. Prior to the 275 upshifts, the filter at Holmehave DWTP had been operated with an ALR of $1.00 \pm 0.09 \mathrm{~g} \mathrm{NH}_{4}{ }^{+}-\mathrm{N} / \mathrm{m}^{3} / \mathrm{h}$ for approximately 7 months. The maximum ammonium removal rate of the filter was $0.64 \mathrm{~g} \mathrm{NH}_{4}{ }^{+} \mathrm{N} / \mathrm{m}^{3} / \mathrm{h}$, regardless of being operated at normal ALRs, or at $1.50 \mathrm{~g} \mathrm{NH}_{4}{ }^{+} \mathrm{N} / \mathrm{m}^{3} / \mathrm{h}$ (Fig. 5B) under a loading rate upshift. Nitrification was incomplete already at low hydraulic loading rates: Ammonium effluent concentrations were as 
279 high as $0.11 \mathrm{mg} \mathrm{NH}_{4}{ }^{+} \mathrm{-N} / \mathrm{L}$, at relatively low filter velocities of approximately $1.5 \mathrm{~m} / \mathrm{h}$ (Fig. 5A). Increasing 280 hydraulic loading rate further increased ammonium effluent concentrations (Fig. 5A). For example, an increase 281 in filter velocity of $75 \%$ increased the effluent concentrations by $109 \%$ to $0.23 \mathrm{mg} \mathrm{NH}_{4}{ }^{+}-\mathrm{N} / \mathrm{L}$. With increasing 282 ammonium effluent concentrations under increasing ALRs, the filter clearly reached its removal capacity, 283 meaning that the filter had no further buffer capacity. This is problematic from a practical point of view, since it 284 constrains treatment plant operation. In order to reduce the effluent concentration, water utilities decrease the water throughput, which in turn makes it challenging to maintain production. Before dosing, the copper concentrations in the filter influent were $<0.01 \mu \mathrm{g} \mathrm{Cu} / \mathrm{L}$, and increased to $0.85 \mu \mathrm{g}$ $287 \mathrm{Cu} / \mathrm{L}(\mathrm{n}=8)$ after dosing onset. The dosing not only facilitated complete ammonium removal at normal ALRs of approximately $1.0 \mathrm{~g} \mathrm{NH}_{4}{ }^{+}-\mathrm{N} / \mathrm{m}^{3} / \mathrm{h}$ (Fig. 2 \& Fig. 5B), but it also enabled the filter to better cope with loading rate increases (Fig. 5A\&B). Ammonium was completely removed when the ALR was upshifted from 1.0 to $1.34 \mathrm{~g}$ $\mathrm{NH}_{4}{ }^{+}-\mathrm{N} / \mathrm{m}^{3} / \mathrm{h}$, only 29 days after dosing onset. In contrast to before copper dosing, ammonium effluent concentrations remained stable at values around the detection limit of $0.01 \mathrm{mg} \mathrm{NH}_{4}{ }^{+} \mathrm{-N} / \mathrm{L}$, with increasing hydraulic loading ranging from 1.8 to $2.9 \mathrm{~m} / \mathrm{h}$ (Fig. 5A). At a filter velocity of $2.6 \mathrm{~m} / \mathrm{h}$ for example, the effluent concentrations were decreased more than 20 times after dosing. However at a filter velocity of $3.9 \mathrm{~m} / \mathrm{h}$ (corresponding to an ALR of $2.05 \mathrm{~g} \mathrm{NH}_{4}{ }^{+} \mathrm{N} / \mathrm{m}^{3} / \mathrm{h}$ ), ammonium effluent concentration was $0.066 \mathrm{mg} \mathrm{NH}{ }_{4}{ }^{+}-\mathrm{N} / \mathrm{L}$ (Fig. 5B), indicating the new (maximum) removal capacity at this time after dosing start was around $1.70 \mathrm{~g}$ $\mathrm{NH}_{4}{ }^{+}-\mathrm{N} / \mathrm{m}^{3} / \mathrm{h}$, more than 2.6 times higher than before the dosing. Nonetheless, the ARR was still lower than ARRs of other biological groundwater filters of for example 3.4 (Lee et al., 2014) or $5 \mathrm{~g} \mathrm{NH}_{4}{ }^{+}-\mathrm{N} / \mathrm{m}^{3} / \mathrm{h}$ (de Vet et al., 2011), probably because those filters had been operated under generally higher ALRs. In theory, operating the filter at Holmehave DWTP under continuously higher ALRs and with copper dosing will lead to increased biomass growth, given constant biomass yield and no other growth limiting factors. Factors such as alkalinity (5.39 meq/L), $\mathrm{pH}$ (7.4), dissolved oxygen (8.32 mg DO/L), and phosphorus (0.053 $\left.\mathrm{mg} \mathrm{PO}_{4}{ }^{3-}-\mathrm{P} / \mathrm{L}\right)$ in the filter influent were not limiting; hence, the increased capacity points towards an opportunity of adding more ammonium to increase ARR even further. 


\subsection{Location of extra ammonium removal capacity over filter depth}

To examine the filter layers active for ammonium removal, the ammonium concentration over filter depth was investigated at Holmehave DWTP at the normal ALR of $1.0 \mathrm{~g} \mathrm{NH}_{4}{ }^{+}-\mathrm{N} / \mathrm{m}^{3} / \mathrm{h}$, before and after dosing. To determine if the extra removal capacity at increased load can be attributed to a specific location in the filter, concentrations over depth were furthermore investigated for the increased ALR of $1.50 \mathrm{~g} \mathrm{NH}_{4}{ }^{+}-\mathrm{N} / \mathrm{m}^{3} / \mathrm{h}$. The depth specific volumetric ammonium removal rates were calculated from the depth concentrations and are denoted $\mathrm{ARR}_{\mathrm{ds}}$.

Before copper dosing, at an ALR of $1.0 \mathrm{~g} \mathrm{NH}_{4}{ }^{+}-\mathrm{N} / \mathrm{m}^{3} / \mathrm{h}$ (filter velocity of $1.92 \mathrm{~m} / \mathrm{h}$ ), ammonium concentrations decreased over filter depth following an almost linear profile (Fig. 6A). The highest $\mathrm{ARR}_{\mathrm{ds}}$ was achieved between 60 and $75 \mathrm{~cm}$ filter depth (Fig. 6C), where ammonium concentrations dropped from 0.196 to $0.121 \mathrm{mg}$ $\mathrm{NH}_{4}{ }^{+}-\mathrm{N} / \mathrm{L}$, which was in accordance with previous observations (Wagner et al., 2016a) where ammonium oxidation also was slightly higher in the deeper regions of the investigated filter. Removal in the filter was not stratified, unlike reported for well-performing nitrifying filters (Lee et al., 2014; Tatari et al., 2016). Nitrite produced from the oxidation of ammonium was oxidized further; hence $\mathrm{NRR}_{\mathrm{ds}}$ was almost equal to $\mathrm{ARR}_{\mathrm{ds}}(\mathrm{Fig}$. 6C\&D). Concentrations were low (Fig. 6B), because ammonium oxidation was limiting the rate of nitrification (Martens-Habbena et al., 2009).

When copper had been dosed for 67 days, ammonium oxidation was significantly increased in the top layer of the filter, leading to highly stratified removal, where all ammonium was removed within $30 \mathrm{~cm}$ depth (Fig. 6A). $\mathrm{ARR}_{\mathrm{ds}}$ from 0 to $10 \mathrm{~cm}$ depth increased by more than 7 -fold, from 0.67 to $4.90 \mathrm{~g} \mathrm{NH}_{4}{ }^{+}-\mathrm{N} / \mathrm{m}^{3} / \mathrm{h}$. The $\mathrm{ARR}_{\mathrm{ds}}$ from 0 to $10 \mathrm{~cm}$ was therefore substantially different from the ARR of $0.98 \mathrm{~g} \mathrm{NH}_{4}{ }^{+}-\mathrm{N} / \mathrm{m}^{3} / \mathrm{h}$, when integrated over the whole active layer of the filter $(75 \mathrm{~cm})$, which shows the value of depth profile information. Nitrite concentrations increased to $0.021 \mathrm{mg} \mathrm{NO}_{2}{ }^{-} \mathrm{N} / \mathrm{L}$ at $10 \mathrm{~cm}$, after which concentrations decreased again (Fig. 6B) and nitrite was safely removed to $<0.002 \mathrm{mg} \mathrm{NO}{ }_{2}^{-}-\mathrm{N} / \mathrm{L}$ after $40 \mathrm{~cm}$ depth. $\mathrm{NRR}_{\mathrm{ds}}$ in the top of the filter were also 
greatly increased compared to before the dosing, and $\mathrm{NRR}_{\mathrm{ds}}$ from 0 to $10 \mathrm{~cm}$ depth was slightly lower than the $\mathrm{ARR}_{\mathrm{ds}}($ Fig. 6C\&D), due to the nitrite peak which was not oxidized further to nitrate at that depth.

On day 68 of the dosing, the ALR was increased by $50 \%$ to $1.50 \mathrm{~g} \mathrm{NH}_{4}{ }^{+} \mathrm{N} / \mathrm{m}^{3} / \mathrm{h}$ (filter velocity of $2.88 \mathrm{~m} / \mathrm{h}$ ). Ammonium removal moved downwards in the filter and $60 \mathrm{~cm}$ filter depth were necessary for complete removal, compared with $30 \mathrm{~cm}$ under normal loading (Fig. 6A); hence, a slightly longer contact time was necessary. At the normal ALR after dosing, ammonium was removed at $30 \mathrm{~cm}$ depth. Hence, $\mathrm{ARR}_{\mathrm{ds}}$ below this depth were 0 , but interestingly, under increased load, the filter exhibited substantial $\mathrm{ARR}_{\mathrm{ds}}$ between 30 and 60

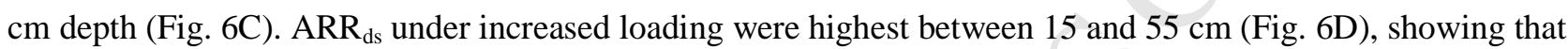
some of the above mentioned extra ammonium removal capacity was located in this layer of the filter. The nitrite concentration profile was also pushed downwards, but nitrite was removed to $<0.002 \mathrm{mg} \mathrm{NO}{ }_{2}{ }^{-}-\mathrm{N} / \mathrm{L}$ after $60 \mathrm{~cm}$ (Fig. 6B). Nitrogen balances over filter depth showed that oxidized ammonium and nitrite was present as nitrite and/or nitrate, confirming nitrification was the governing process.

The depth profile investigation revealed that the increased nitrification efficiency stemmed from a faster oxidation of ammonium in the upper layers of the filter. Additional capacity for ammonium removal at increased ALR was located between 15 and $55 \mathrm{~cm}$, showing that copper dosing stimulated nitrification activity also in the deeper parts of the filter. Average effluent copper measurements (67 and 68 days with dosing) of $0.52 \mu \mathrm{g} \mathrm{Cu} / \mathrm{L}$ confirmed that copper fully penetrated the filter. The findings document that copper dosing activated the whole filter, which is important for practical dosing applications.

\section{Conclusions}

Overall, copper dosing increased nitrification efficiency at different full-scale drinking water treatment plants, which had struggled with poor nitrification performance for several years. The stimulation of ammonium removal was generic - regardless of differences in raw water chemistry, treatment plant configuration, filter design and operation, and ammonium loading rates. 
- At 10 out of 10 different DWTPs, copper dosing at $\leq 1.5 \mu \mathrm{g} \mathrm{Cu} / \mathrm{L}$ fully remediated nitrification within only 2-3 weeks. With dosing, ammonium removal rates increased on average by $87 \%$, and most filters achieved very low effluent ammonium concentrations of $<0.01 \mathrm{mg} \mathrm{NH}_{4}{ }^{+}$-N/L.

- Full nitrification was established relatively quickly (19 days on average). Dosing filters receiving prefiltered water achieved complete ammonium removal faster, than filters without primary filtration, possibly related with that those filters received considerably higher iron loads, which may have precipitated or bound the copper.

- Poor nitrification performance can constrain DWTPs operation. When the filter velocity was increased by 75 $\%$ in a filter operating at its ammonium removal capacity, the ammonium effluent concentrations increased by $109 \%$, causing a deterioration of the finished water quality. With dosing, at the same increased filter velocity, effluent concentrations were $<0.01 \mathrm{mg} \mathrm{NH}_{4}{ }^{+}$-N/L and more than 20 times lower than without the dosing.

- With dosing, biofilters could efficiently remove ammonium at loadings even beyond the loading rates the filters were normally operated under. Under short-term loading rate upshifts, the removal capacity of a filter was increased by more than 2.6 times, showing that copper dosing can not only remediate existing problems, but also increase the robustness of these filters. The extra capacity makes filters resilient towards loading rate upshifts/fluctuations.

- The increased resilience was brought about by ammonium and nitrite oxidation being shifted further up in the filter. Under increased loading rates, extra removal capacity was located at the depth of 15 to $55 \mathrm{~cm}$, showing that copper dosing activated the whole filter. Water depth sampling furthermore revealed significant, but transient nitrite peaks. These were subsequently oxidized further to effluent concentrations $<0.002 \mathrm{mg} \mathrm{NO}_{2}^{-}-\mathrm{N} / \mathrm{L}$, thereby preventing problematic nitrite breakthrough. 
Our results suggest copper dosing as a technology with the potential of solving many cases of insufficient nitrification at drinking water treatment plants, with the perspective of achieving even lower ammonium and nitrite effluent concentrations and operation under higher flow rates. Higher rates and increased nitrification efficiency in general indicate the possibility of treating the same amount of water with less filter area, thereby decreasing the geographical footprint.

\section{Acknowledgments}

The study was supported by the Water Sector's Technology development Fund (VTUF) through project

'Stimulated biological treatment' (SBB) and by DTU. The authors gratefully acknowledge all water utilities that have contributed to the study: Fosyningen Allerød Rudersdal A/S, Fors A/S (Holbæk Forsyning), Vordingborg Forsyning, SK Forsyning A/S, Hillerød Forsyning, and Skive Vand. Special thanks go furthermore to Anne Esbjørn from VandCenter Syd, Henrik Nicolaisen from Glostrup Forsyning, and Søren Tygesen from DIN Forsyning, and to Charlotte Jensen and Sonsoles Quinzaños from Krüger Veolia for assistance throughout the project.

\section{References}

Albrechtsen, H.-J., Wagner, F.B., Nielsen, P.B., Boe-Hansen, R., Fischer, E.V., 2015. Apparatus comprising trace element dosage and method for treating raw water in biofilter. Patent application. Patent number: WO2015132283.

Amin, S.A., Moffett, J.W., Martens-Habbena, W., Jacquot, J.E., Han, Y., Devol, A., Ingalls, A.E., Stahl, D.A., Armbrust, E.V., 2013. Copper requirements of the ammonia-oxidizing archaeon Nitrosopumilus maritimus SCM1 and implications for nitrification in the marine environment. Limnol. Oceanogr. 58, 2037-2045. 
doi:10.4319/lo.2013.58.6.2037

APHA, AWWA, WEF, 2005. Standard Methods for the Examination of Water and Wastewater, 21st ed. American Public Health Association, Washington, DC. doi:10.2105/AJPH.51.6.940-a

Benjamin, M.M., Sletten, R.S., Bailey, R.P., Bennett, T., 1996. Sorption and filtration of metals using ironoxide-coated sand. Water Res. 30, 2609-2620. doi:10.1016/S0043-1354(96)00161-3

Daims, H., Lebedeva, E. V., Pjevac, P., Han, P., Herbold, C., Albertsen, M., Jehmlich, N., Palatinszky, M.,

Danish Nature Agency, 2014. Kvaliteten af det danske drikkevand for perioden 2011-2013 (Quality of the Danish drinking water for the period 2011-2013, in Danish). Copenhagen, Denmark.

Danish Nature Agency, 2012. Kvaliteten af det danske drikkevand for perioden 2008-2010 (Quality of the Danish drinking water for the period 2008-2010, in Danish). Copenhagen, Denmark.

Danish Nature Agency, 2009. Kvaliteten af det danske drikkevand for perioden 2005-2007 (Quality of the Danish drinking water for the period 2005-2007, in Danish). Copenhagen, Denmark.

Danish Nature Agency, 2007. Kvaliteten af det danske drikkevand for perioden 2002-2004 (Quality of the Danish drinking water for the period 2002-2004, in Danish). Copenhagen, Denmark.

de Vet, W.W.J.M., Kleerebezem, R., van der Wielen, P.W.J.J., Rietveld, L.C., van Loosdrecht, M.C.M., 2011. Assessment of nitrification in groundwater filters for drinking water production by qPCR and activity 
measurement. Water Res. 45, 4008-4018. doi:10.1016/j.watres.2011.05.005

European Comission, 1998. Council Directive 98/83/EC on the quality of water intended for human consumption, Official Journal of the European Communities. doi:2004R0726 - v.7 of 05.06.2013

Geological Survey of Denmark and Greenland, 2016. National well database (Jupiter) [WWW Document]. Geol. Surv. Denmark Greenl. URL http://www.geus.dk/DK/data-maps/jupiter/Sider/default.aspx (accessed 3.3.17).

Gülay, A., Tatari, K., Musovic, S., Mateiu, R. V., Albrechtsen, H.J., Smets, B.F., 2014. Internal porosity of mineral coating supports microbial activity in rapid sand filters for groundwater treatment. Appl. Environ. Microbiol. 80, 7010-7020. doi:10.1128/AEM.01959-14

Kors, L.J., Moorman, J.H.N., Wind, A.P.M., Van Der Hoek, J.P., 1998. Nitrification and low temperature in a raw water reservoir and rapid sand filters. Water Sci. Technol. 37, 169-176. doi:10.1016/S02731223(98)00021-3

Laurent, P., Kihn, A., Andersson, A., Servais, P., 2003. Impact of backwashing on nitrification in the biological activated carbon filters used in drinking water treatment. Environ. Technol. 24, 277-287. doi:10.1080/09593330309385560

Lee, C.O., Boe-Hansen, R., Musovic, S., Smets, B., Albrechtsen, H.J., Binning, P., 2014. Effects of dynamic operating conditions on nitrification in biological rapid sand filters for drinking water treatment. Water Res. 64, 226-236. doi:10.1016/j.watres.2014.07.001

Lopato, L., Röttgers, N., Binning, P.J., Arvin, E., 2013. Heterogeneous Nitrification in a Full-Scale Rapid Sand Filter Treating Groundwater. J. Environ. Eng. 139, 375-384. doi:10.1061/(ASCE)EE.1943-7870.0000653

Martens-Habbena, W., Berube, P.M., Urakawa, H., de la Torre, J.R., Stahl, D.A., 2009. Ammonia oxidation 
kinetics determine niche separation of nitrifying Archaea and Bacteria. Nature 461, 976-979. doi:10.1038/nature08465

Ministry of Environment and Food of Denmark, 2016. Bekendtgørelse om vandkvalitet og tilsyn med vandforsyningsanlæg (Statuary order on water quality and surveillence of water supply facilities, in Danish). Ressortministerium: Miljø- og Fødevareministeriet, Administrerende myndighed: Naturstyrelsen.

Palomo, A., Jane Fowler, S., Gülay, A., Rasmussen, S., Sicheritz-Ponten, T., Smets, B.F., 2016. Metagenomic analysis of rapid gravity sand filter microbial communities suggests novel physiology of Nitrospira spp. ISME J. 10, 2569-2581. doi:10.1038/ismej.2016.63

Prest, E.I., Hammes, F., van Loosdrecht, M.C.M., Vrouwenvelder, J.S., 2016. Biological stability of drinking water: Controlling factors, methods, and challenges. Front. Microbiol. 7, 1-24. doi:10.3389/fmicb.2016.00045

Prosser, J.I., 1989. Autotrophic Nitrification in Bacteria, in: Rose, A.H., Tempest, D.W. (Eds.), Advances in Microbial Physiology. Academic Press. doi:10.1017/CBO9781107415324.004

Sayavedra-Soto, L.A., Arp, D.J., 2011. Ammonia-oxidizing bacteria: Their biochemistry and molecular biology, in: Ward, B.B., Arp, D.J., Klotz, M.G. (Eds.), Nitrification. ASM Press, Washington, DC, pp. 9-114. doi:10.1002/9781118143391

Stamer, C., Nielsen, P.B., 2005. Behandling af reduceret vand på mindre vandværker (Treatment of reduced water at smaller water works, in Danish). Copenhagen, Denmark.

Sylva, R., 1976. The environmental chemistry of copper (II) in aquatic systems. Water Res. 10, 789-792. doi:10.1016/0043-1354(76)90097-X

Tatari, K., Smets, B.F., Albrechtsen, H.J., 2016. Depth investigation of rapid sand filters for drinking water 
production reveals strong stratification in nitrification biokinetic behavior. Water Res. 101, 402-410. doi:10.1016/j.watres.2016.04.073

USEPA, 2007. Inductively Coupled Plasma-Mass Spectometry, EPA 6020A. USEPA Off. Res. Dev. Washingt. van der Kooij, D., 2000. Biological Stability: a Multidimensional Quality Aspect of Treated Water. Water. Air. Soil Pollut. 123, 25-34. doi:Doi 10.1023/A:1005288720291

van Kessel, M.A.H.J., Speth, D.R., Albertsen, M., Nielsen, P.H., Op den Camp, H.J.M., Kartal, B., Jetten, M.S.M., Lücker, S., 2015. Complete nitrification by a single microorganism. Nature 528, 555-+. doi:10.1038/nature16459

Wagner, F.B., Nielsen, P.B., Boe-Hansen, R., Albrechtsen, H.J., 2016a. Copper deficiency can limit nitrification in biological rapid sand filters for drinking water production. Water Res. 95, 280-288. doi:10.1016/j.watres.2016.03.025

Wagner, F.B., Nielsen, P.B., Boe-Hansen, R., Albrechtsen, H.J., 2016b. Copper dosing to biological rapid sand filters increases nitrifier activity and abundance. In: Proceedings of the IWA Specialist Conference on Microbial Ecology and Water Engineering 2016, Copenhagen, Denmark, pp. 102-103.

WHO, 2011. World Health Organization Guidelines for drinking-water Quality, 4th ed. Geneva, Switzerland.

Zhang, Y., Edwards, M., 2010. Nutrients and metals effects on nitrification in drinking water systems. J. / Am. Water Work. Assoc. 102, 56-66.

Zhang, Y., Love, N., Edwards, M., 2009. Nitrification in Drinking Water Systems. Crit. Rev. Environ. Sci. Technol. 39, 153-208. doi:10.1080/10643380701631739 
Table and figure captions:

Table 1: Raw water chemistry for all drinking water treatment plants investigated. Values are weighted averages, which take into account abstraction ratios from different boreholes. (adapted from Geological Survey of Denmark and Greenland, 2016)

Table 2: Characteristics and nitrification performance indicators of all investigated DWTP

Figure 1: Long-term time series of ammonium effluent concentrations at the investigated DWTPs. Data points were normalized to the onset of copper dosing on day 0 . The shaded area visualizes the dosing period. Longterm data for Skive DWTP was not available, as the plant was just newly started up. (with data adapted from Geological Survey of Denmark and Greenland, 2016)

Figure 2: Effect of copper dosing on volumetric ammonium removal rates (ARR) vs. volumetric ammonium loading rates (ALR) for all 10 investigated DWTPs. Full symbols depict 'before' and empty symbols 'after Cu dosing'. The diagonal line indicates complete removal of ammonium (when ARR=ALR) and numbers by the empty symbols indicate duration of copper dosing until the respective ARR was reached. Grey star Glostrup: status at Glostrup DWTP with passive dosing.

Figure 3: Duration of copper dosing until complete ammonium removal (ARR=ALR) was achieved, and volumetric ammonium loading rates, for the investigated DWTPs. Plants are separated into two groups: plants where copper was dosed to filters receiving prefiltered water and plants where primary filtration is not used.

Figure 4: Effect of copper dosing over time on ammonium removal rates (ARR) at Glostrup DWTP, and response of ARRs to volumetric ammonium loading rate (ALR). The dashed line depicts onset of active electrode dosing. 
499 Figure 5: Effect of copper dosing on ammonium removal at increased loading rates (Holmehave DWTP). A:

500 Ammonium effluent concentrations for different filter velocities. B: Volumetric ammonium removal rates

501 (ARR) vs. volumetric ammonium loading rates (ALR). Different symbols depict three phases in relation to

502 copper dosing.

503 Figure 6: Effect of dosing on ammonium and nitrite removal over filter depth, at normal and increased

504 ammonium loading rates (Holmehave DWTP). A: Ammonium, B: nitrite concentrations, C: depth specific

505 ammonium removal rate, and D: depth specific nitrite removal rate, before and after copper dosing at a filter

506 velocity of $1.92 \mathrm{~m} / \mathrm{h}$, and after copper dosing with increased loading rate at $2.88 \mathrm{~m} / \mathrm{h}$. 
Table 1: Raw water chemistry for all drinking water treatment plants investigated. Values are weighted averages, which take into account abstraction ratios from different boreholes. (adapted from Geological Survey of Denmark and Greenland, 2016)

\begin{tabular}{|c|c|c|c|c|c|c|c|c|c|c|}
\hline DWTP & Nærum & Langerød & Bakkebølle & Skindermarken & Glostrup & Holmehave & Mørkeskov & Valbygård & Frederiksgade & Skive \\
\hline Temp $\left[{ }^{\circ} \mathrm{C}\right]$ & 9.2 & 9.3 & 9.4 & 9.0 & 9.9 & 9.4 & 9.8 & 9.0 & 9.4 & 8.3 \\
\hline $\mathrm{pH}[-]$ & 7.5 & 7.4 & 7.1 & 8.2 & 7.5 & 7.4 & 7.2 & 7.4 & 7.3 & 8.0 \\
\hline Dissolved oxygen $[\mathrm{mg} / \mathrm{L}]$ & 0.6 & 0.9 & 0.4 & 0.5 & 0.4 & 1.5 & $<0.1$ & 0.3 & 1.2 & $<0.1$ \\
\hline $\mathrm{NH}_{4}^{+}[\mathrm{mg} \mathrm{N} / \mathrm{L}]$ & 0.34 & 1.05 & 1.10 & 0.87 & 0.77 & 0.39 & 1.34 & 0.70 & 0.63 & 0.17 \\
\hline $\mathrm{NO}_{2}^{-}[\mathrm{mg} \mathrm{N} / \mathrm{L}]$ & 0.002 & 0.005 & 0.002 & 0.002 & $<0.001$ & 0.002 & 0.002 & 0.005 & $<0.001$ & $<0.001$ \\
\hline $\mathrm{NO}_{3}{ }^{-}[\mathrm{mg} \mathrm{N} / \mathrm{L}]$ & 0.07 & 0.01 & 0.08 & 0.07 & 0.05 & 0.06 & 0.11 & 0.07 & 0.02 & 0.09 \\
\hline total $\mathrm{Fe}[\mathrm{mg} / \mathrm{L}]$ & 2.50 & 3.05 & 1.43 & 0.27 & 1.89 & 1.56 & 0.70 & 1.99 & 1.50 & 0.51 \\
\hline total $\mathrm{Mn}[\mathrm{mg} / \mathrm{L}]$ & 0.09 & 0.12 & 0.01 & 0.05 & 0.06 & 0.32 & 0.01 & 0.09 & 0.03 & 0.28 \\
\hline $\mathrm{H}_{2} \mathrm{~S}[\mathrm{mg} / \mathrm{L}]$ & $<0.02$ & 0.03 & 0.47 & 0.03 & 0.03 & NA & 0.26 & 0.04 & 0.04 & $<0.05$ \\
\hline $\mathrm{CH}_{4}[\mathrm{mg} / \mathrm{L}]$ & 0.01 & 0.03 & 2.11 & 0.23 & 0.02 & NA & 1.26 & 0.03 & 1.04 & 0.02 \\
\hline $\mathrm{P}[\mathrm{mg} / \mathrm{L}]$ & 0.020 & 0.251 & 0.031 & 0.210 & 0.032 & 0.088 & 0.022 & 0.153 & 0.051 & 0.148 \\
\hline $\begin{array}{c}\text { Alkalinity [as } \mathrm{mg} \mathrm{HCO}_{3}^{-} \\
\text {/L] }\end{array}$ & 342 & 358 & 406 & 265 & 448 & 308 & 408 & 398 & 349 & 150 \\
\hline $\mathrm{Ca}^{2+}[\mathrm{mg} / \mathrm{L}]$ & 114 & 86 & 86 & 45 & 105 & 89 & 93 & 70 & 68 & 61 \\
\hline $\mathrm{Mg}^{2+}[\mathrm{mg} / \mathrm{L}]$ & 18 & 14 & 21 & 16 & 39 & 12 & 24 & 16 & 25 & 5 \\
\hline $\mathrm{Cl}^{-}[\mathrm{mg} / \mathrm{L}]$ & 56 & 52 & 31 & 66 & 108 & 41 & 99 & 117 & 46 & 33 \\
\hline $\mathrm{SO}_{4}{ }^{2-}[\mathrm{mg} / \mathrm{L}]$ & 49 & 8 & 13 & 0.3 & 60 & 34 & 16 & 23 & 6 & 51 \\
\hline NVOC [mg/L] & 2.1 & 2.6 & 2.5 & 1.0 & 2.0 & 2.0 & 2.7 & 2.4 & 2.9 & 1.1 \\
\hline
\end{tabular}

NA: not available 
Table 2: Characteristics and nitrification performance indicators of all investigated DWTP

\begin{tabular}{|c|c|c|c|c|c|c|c|c|c|c|c|c|c|c|}
\hline DWTP & $\begin{array}{c}\text { Water } \\
\text { abstrac } \\
\text { ted } \\
{\left[10^{6}\right.} \\
\left.\mathrm{m}^{3}\right] \text { in } \\
\text { (year) } \\
\end{array}$ & Treatment train & $\begin{array}{l}\text { Filter material of } \\
\text { filter with dosing }\end{array}$ & $\begin{array}{l}\text { Depth } \\
\text { of } \\
\text { active } \\
\text { layer } \\
\text { [m] }\end{array}$ & $\begin{array}{l}\text { Filter } \\
\text { velocity } \\
\text { before/ } \\
\text { after } \mathrm{Cu} \\
{[\mathrm{m} / \mathrm{h}]}\end{array}$ & $\begin{array}{c}\text { EBCT } \\
{[\mathrm{h}]^{*}}\end{array}$ & $\begin{array}{l}\text { Cu dosing } \\
\text { method }\end{array}$ & $\begin{array}{c}\text { Cu influent } \\
\text { conc. } \\
\text { before/after } \\
\text { dosing } \\
{[\mu \mathrm{g} / \mathrm{L}]} \\
\end{array}$ & $\begin{array}{c}\text { Ammonium } \\
\text { influent } \\
\text { conc. } \\
\text { before/after } \\
\text { dosing } \\
\text { [mg N/L] } \\
\end{array}$ & $\begin{array}{l}\text { Ammonium } \\
\text { effluent } \\
\text { conc. } \\
\text { before/after } \\
\text { dosing } \\
\text { [mg N/L] } \\
\end{array}$ & $\begin{array}{c}\text { Nitrite } \\
\text { effluent } \\
\text { conc. } \\
\text { before/after } \\
\text { dosing } \\
\text { [mg N/L] }\end{array}$ & $\begin{array}{l}\text { Total iron } \\
\text { conc. in the } \\
\text { influent to } \\
\text { the filter } \\
\text { with dosing } \\
\text { [mg Fe/L] }\end{array}$ & $\begin{array}{c}\text { Volumetric } \\
\text { ammonium } \\
\text { loading rate } \\
\text { before/after } \\
\text { dosing } \\
{\left[\mathrm{g} \mathrm{N} / \mathrm{m}^{3} / \mathrm{h}\right]}\end{array}$ & $\begin{array}{l}\text { Response } \\
\text { for } \\
\text { complete } \\
\text { ammonium } \\
\text { removal } \\
\text { [days] }\end{array}$ \\
\hline $\begin{array}{c}\text { Nærum } \\
\text { (Wagner et } \\
\text { al., 2016) }\end{array}$ & $\begin{array}{c}0.85 \\
(2014)\end{array}$ & $\begin{array}{l}\text { stairs aeration } \rightarrow \\
\text { single stage rapid } \\
\text { sand filtration }\end{array}$ & 0.8-1.4 mm quartz & 0.60 & 1.56 & 0.38 & $\begin{array}{l}\text { Active (solid } \\
\text { electrode) }\end{array}$ & $<0.01 / 0.97$ & $0.34 / 0.35$ & $0.19 /<0.01$ & $\begin{array}{l}0.009 / \\
0.006\end{array}$ & 2.06 & $0.88 / 0.90$ & 22 \\
\hline Langerød & $\begin{array}{c}1.47 \\
(2015)\end{array}$ & $\begin{array}{l}\text { stairs aeration } \rightarrow \\
\text { rapid sand } \\
\text { prefiltration } \rightarrow \text { rapid } \\
\text { sand afterfiltration }\end{array}$ & 0.8-1.4 mm quartz & 0.65 & 2.40 & 0.27 & $\begin{array}{l}\text { Passive } \\
\text { (solid } \\
\text { structure) }\end{array}$ & $<0.03 / 0.42$ & $0.75 / 0.76$ & $0.33 /<0.02$ & $<0.002 / \mathrm{NA}$ & 0.14 & $2.77 / 2.81$ & 12 \\
\hline Bakkebølle & $\begin{array}{c}0.20 \\
(2015)\end{array}$ & $\begin{array}{l}\text { INKA aeration } \rightarrow \\
\text { rapid sand } \\
\text { prefiltration } \rightarrow \text { rapid } \\
\text { sand afterfiltration }\end{array}$ & $\begin{array}{l}1-3 \mathrm{~mm} \text { granular } \\
\text { calcium carbonate }\end{array}$ & 0.70 & 1.07 & 0.65 & $\begin{array}{l}\text { Passive } \\
\text { (solid } \\
\text { structure) }\end{array}$ & $<0.03 / 1.50$ & $0.89 / 0.91$ & $0.49 / 0.03$ & $<0.002$ & 0.08 & $1.37 / 1.41$ & 17 \\
\hline $\begin{array}{l}\text { Skinder- } \\
\text { marken }\end{array}$ & $\begin{array}{c}0.61 \\
(2016)\end{array}$ & $\begin{array}{c}\text { plate aeration } \rightarrow \\
\text { rapid sand } \\
\text { prefiltration } \rightarrow \text { rapid } \\
\text { sand afterfiltration }\end{array}$ & $\begin{array}{c}0.4-0.8 \mathrm{~mm} \text { quartz } \\
(20 \mathrm{~cm}) \rightarrow 0.8-1.4 \\
\mathrm{~mm} \text { quartz }(25 \\
\mathrm{cm}) \rightarrow 1.3-2.0 \\
\mathrm{~mm} \text { quartz }(15 \\
\mathrm{cm})\end{array}$ & 0.60 & 1.30 & 0.46 & $\begin{array}{l}\text { Passive } \\
\text { (solid } \\
\text { structure) }\end{array}$ & $\begin{array}{c}<0.04 / \\
0.29 \\
\text { (effluent) }\end{array}$ & 0.35 & $0.08 /<0.01$ & $\begin{array}{l}0.003 / \\
<0.002\end{array}$ & 0.06 & 0.76 & 13 \\
\hline \multirow[t]{2}{*}{ Glostrup } & \multirow[t]{2}{*}{$\begin{array}{c}0.54 \\
(2016)\end{array}$} & \multirow{2}{*}{$\begin{array}{l}\text { stairs aeration } \rightarrow \\
\text { contact basin } \rightarrow \\
\text { single stage rapid } \\
\text { sand filtration }\end{array}$} & \multirow[t]{2}{*}{ 0.8-1.4 mm quartz } & \multirow[t]{2}{*}{0.80} & $2.57 / 2.71$ & $\begin{array}{l}0.31 / \\
0.30\end{array}$ & $\begin{array}{l}\text { Passive } \\
\text { (solid } \\
\text { structure) }\end{array}$ & $<0.01 / 0.36$ & 0.38 & $0.18 / 0.17$ & $<0.002$ & \multirow[t]{2}{*}{1.32} & $1.22 / 1.29$ & no effect \\
\hline & & & & & $2.71 / 2.80$ & $\begin{array}{l}0.30 / \\
0.29\end{array}$ & $\begin{array}{l}\text { Active (solid } \\
\text { electrode) }\end{array}$ & $<0.01 / 0.91$ & $0.38 / 0.37$ & $0.17 /<0.01$ & $<0.002$ & & $1.29 / 1.30$ & 30 \\
\hline Holmehave & $\begin{array}{c}3.56 \\
(2015)\end{array}$ & $\begin{array}{l}\text { plate aeration } \rightarrow \\
\text { single stage rapid } \\
\text { sand filtration }\end{array}$ & 0.8-1.4 mm quartz & 0.75 & 1.92 & 0.39 & $\begin{array}{l}\text { Active (solid } \\
\text { electrode) }\end{array}$ & $<0.01 / 1.34$ & $0.38 / 0.40$ & $0.14 /<0.01$ & $<0.002$ & 1.46 & $0.97 / 1.03$ & 21 \\
\hline Mørkeskov & $\begin{array}{c}0.40 \\
(2015)\end{array}$ & $\begin{array}{l}\text { stairs aeration } \rightarrow \\
\text { contact basin } \rightarrow \\
\text { single stage } \\
\text { pressurized sand } \\
\text { filtration }\end{array}$ & $\begin{array}{c}0.8-1.4 \mathrm{~mm} \\
\text { quartz }(200 \mathrm{~cm}) \\
\rightarrow 1.2-2.0 \mathrm{~mm} \\
\text { quartz }(50 \mathrm{~cm})\end{array}$ & 2.50 & 6.46 & 0.39 & $\begin{array}{l}\text { Active (solid } \\
\text { electrode) }\end{array}$ & NA/NA & $1.01 / 1.17$ & $0.47 /<0.01$ & $\begin{array}{l}0.006 / \\
<0.002\end{array}$ & $0.7^{+}$ & $2.61 / 3.02$ & 21 \\
\hline Valbygård & $\begin{array}{c}1.67 \\
(2015)\end{array}$ & $\begin{array}{l}\text { INKA aeration } \rightarrow \\
\text { rapid sand } \\
\text { prefiltration } \rightarrow \text { rapid } \\
\text { sand afterfiltration }\end{array}$ & 1.6-2.2 mm quartz & 0.80 & 1.62 & 0.49 & $\begin{array}{l}\text { Active (solid } \\
\text { electrode) }\end{array}$ & $\begin{array}{c}<0.02 \text { / } \\
0.15 \\
\text { (effluent) }\end{array}$ & 0.70 & $0.28 /<0.01$ & $<0.002$ & NA & 1.43 & 20 \\
\hline $\begin{array}{l}\text { Frederiks- } \\
\text { gade }\end{array}$ & $\begin{array}{c}1.36 \\
(2015)\end{array}$ & $\begin{array}{l}\text { Cascade aeration } \\
\rightarrow \text { rapid sand } \\
\text { prefiltration } \rightarrow \text { rapid } \\
\text { sand afterfiltration }\end{array}$ & $1.0-2.0 \mathrm{~mm}$ quartz & 0.72 & 2.41 & 0.30 & $\begin{array}{l}\text { Active (solid } \\
\text { electrode) }\end{array}$ & $<0.01 / 0.66$ & $0.38 / 0.37$ & $0.15 /<0.01$ & $<0.002$ & 0.01 & $1.27 / 1.24$ & 14 \\
\hline Skive & $\begin{array}{c}1.38 \\
(2016)\end{array}$ & $\begin{array}{c}\mathrm{O}_{2} \text { injection } \rightarrow \\
\text { single stage } \\
\text { pressurized sand } \\
\text { filtration }\end{array}$ & 0.8-1.4 mm quartz & 1.20 & $1.62 / 2.43$ & $\begin{array}{l}0.74 / \\
0.49\end{array}$ & $\begin{array}{c}\text { Active } \\
\text { (liquid from } \\
\mathrm{CuSO}_{4} \text { ) }\end{array}$ & $<0.04 / 1.50$ & $0.22 / 0.15$ & $0.15 / 0.03$ & NA/NA & $0.51^{+}$ & 0.3 & 22 \\
\hline
\end{tabular}




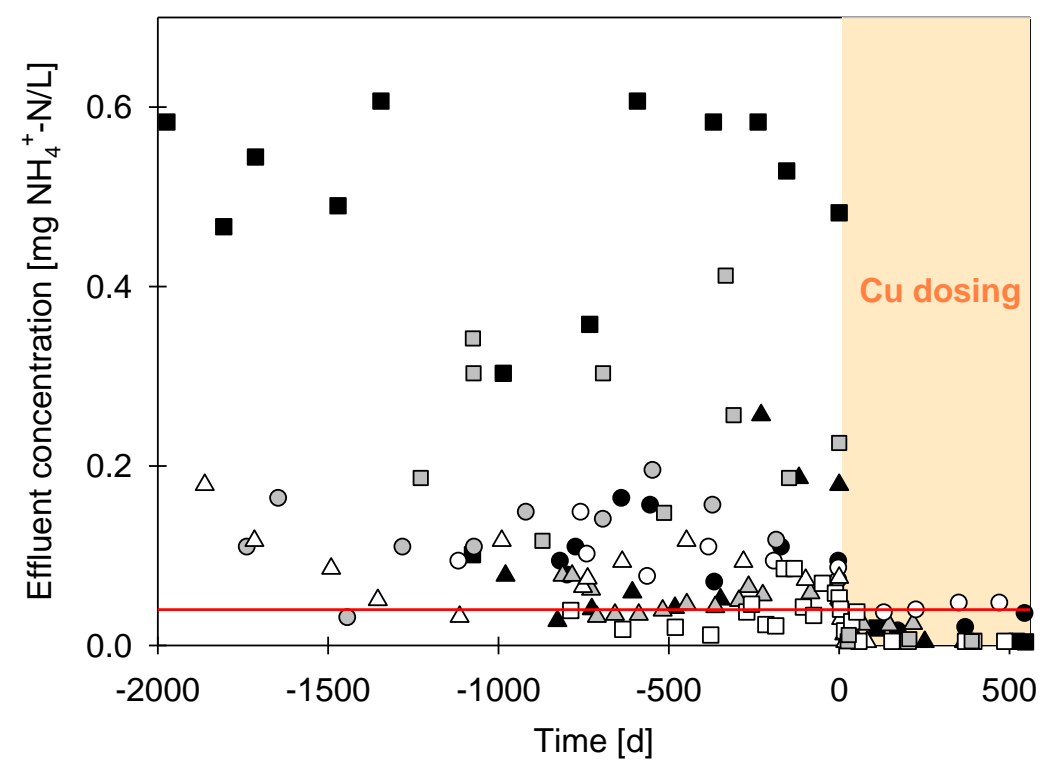

\begin{tabular}{cllll}
\hline - & Nærum & $\square$ & Mørkeskov \\
$\Delta$ & Langerød & $\bigcirc$ & Valbygård \\
口 & Bakkebølle & $\triangle$ & Frederiksgade \\
0 & Glostrup & $\square$ & Skindermarken \\
$\triangle$ & Holmehave & & $\mathrm{NH}_{4}^{+}$guideline
\end{tabular}

Figure 1: Long-term time series of ammonium effluent concentrations at the investigated DWTPs. Data points were normalized to the onset of copper dosing on day 0 . The shaded area visualizes the dosing period. Longterm data for Skive DWTP was not available, as the plant was just newly started up. (with data adapted from Geological Survey of Denmark and Greenland, 2016) 


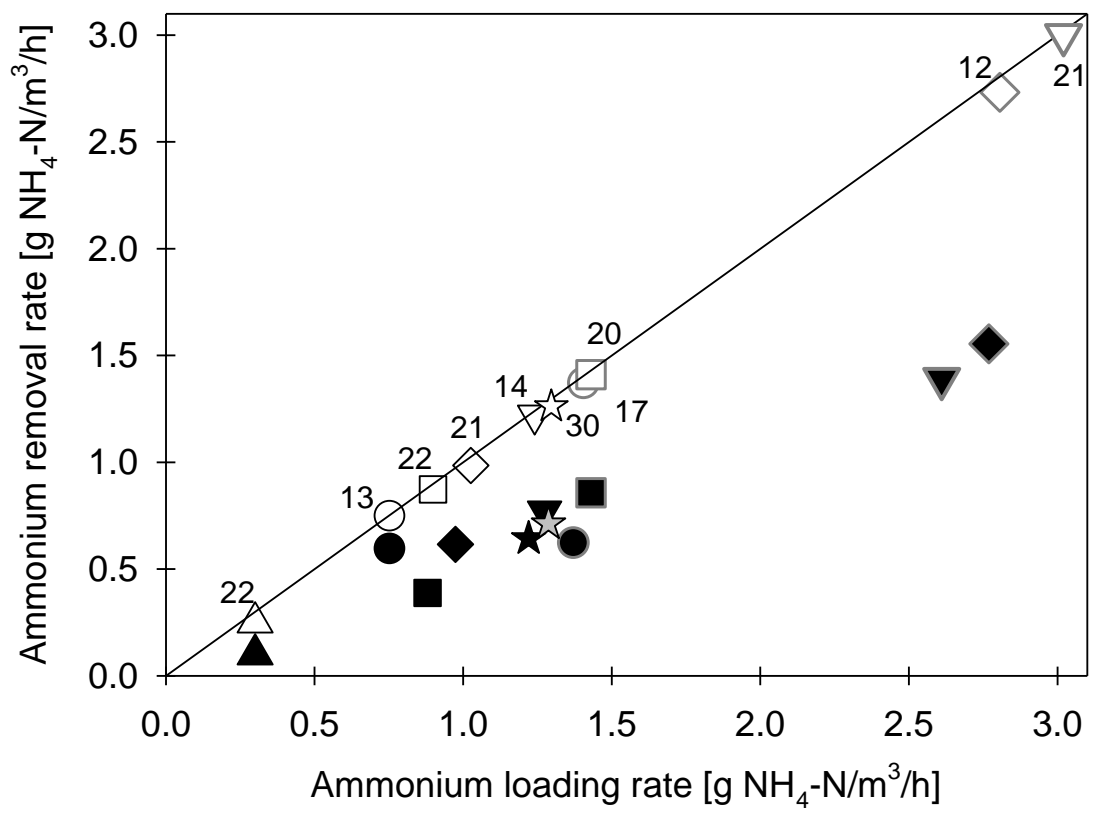

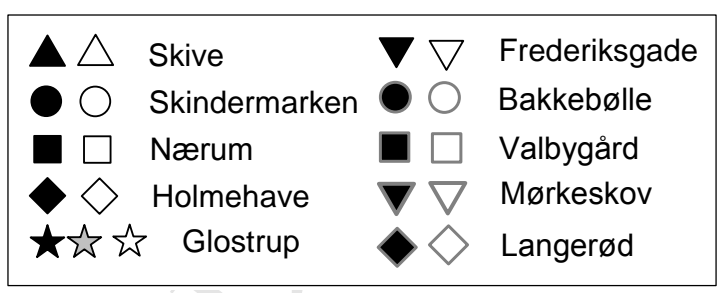

Figure 2: Effect of copper dosing on volumetric ammonium removal rates (ARR) vs. volumetric ammonium loading rates (ALR) for all 10 investigated DWTPs. Full symbols depict 'before' and empty symbols 'after Cu dosing'. The diagonal line indicates complete removal of ammonium (when ARR=ALR) and numbers by the empty symbols indicate duration of copper dosing until the respective ARR was reached. Grey star Glostrup: status at Glostrup DWTP with passive dosing. 


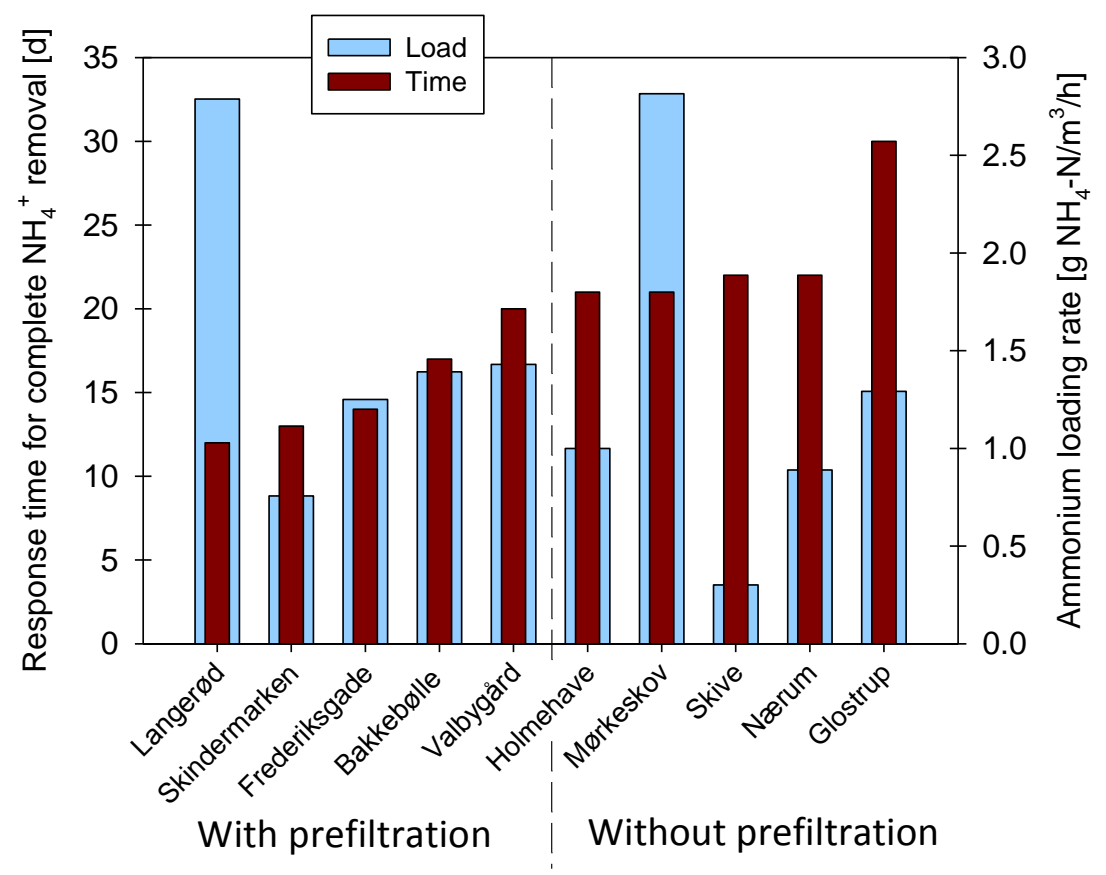

Figure 3: Duration of copper dosing until complete ammonium removal (ARR=ALR) was achieved, and volumetric ammonium loading rates, for the investigated DWTPs. Plants are separated into two groups: plants where copper was dosed to filters receiving prefiltered water and plants where primary filtration is not used. 


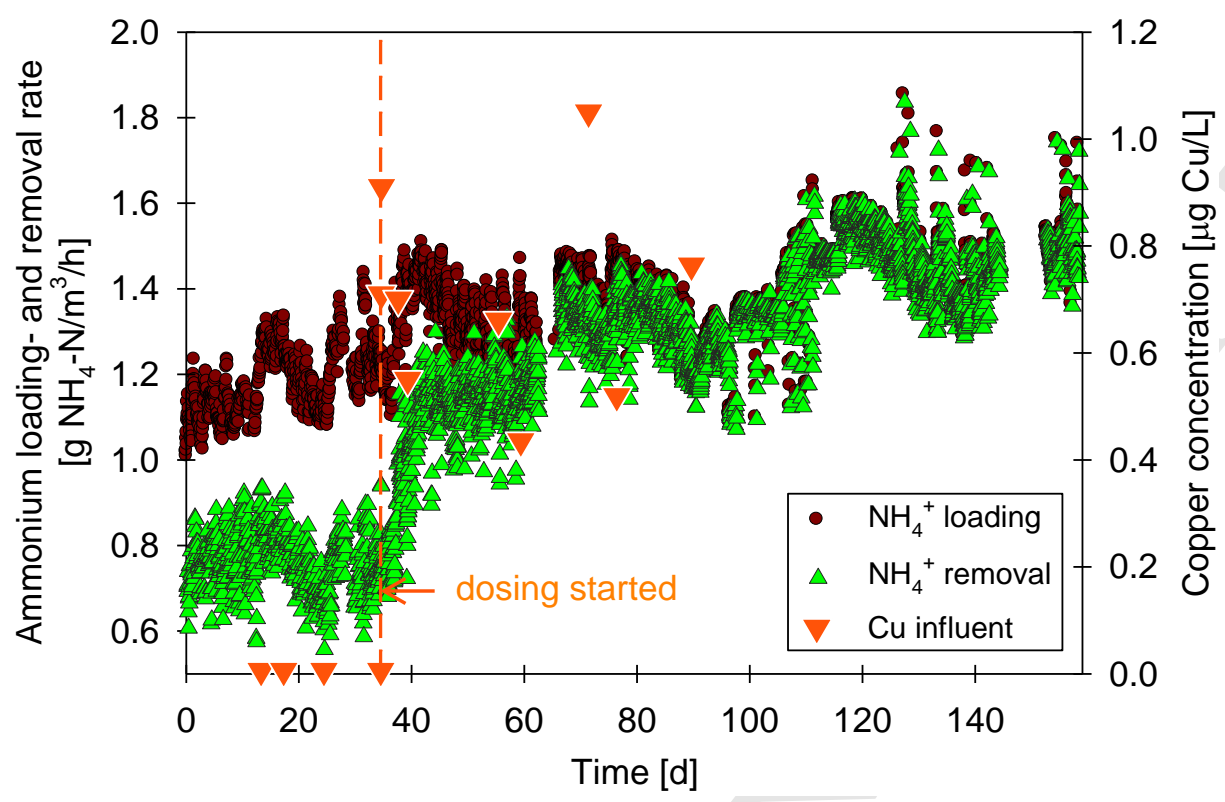

Figure 4: Effect of copper dosing over time on ammonium removal rates (ARR) at Glostrup DWTP, and response of ARRs to volumetric ammonium loading rate (ALR). The dashed line depicts onset of active electrode dosing. 

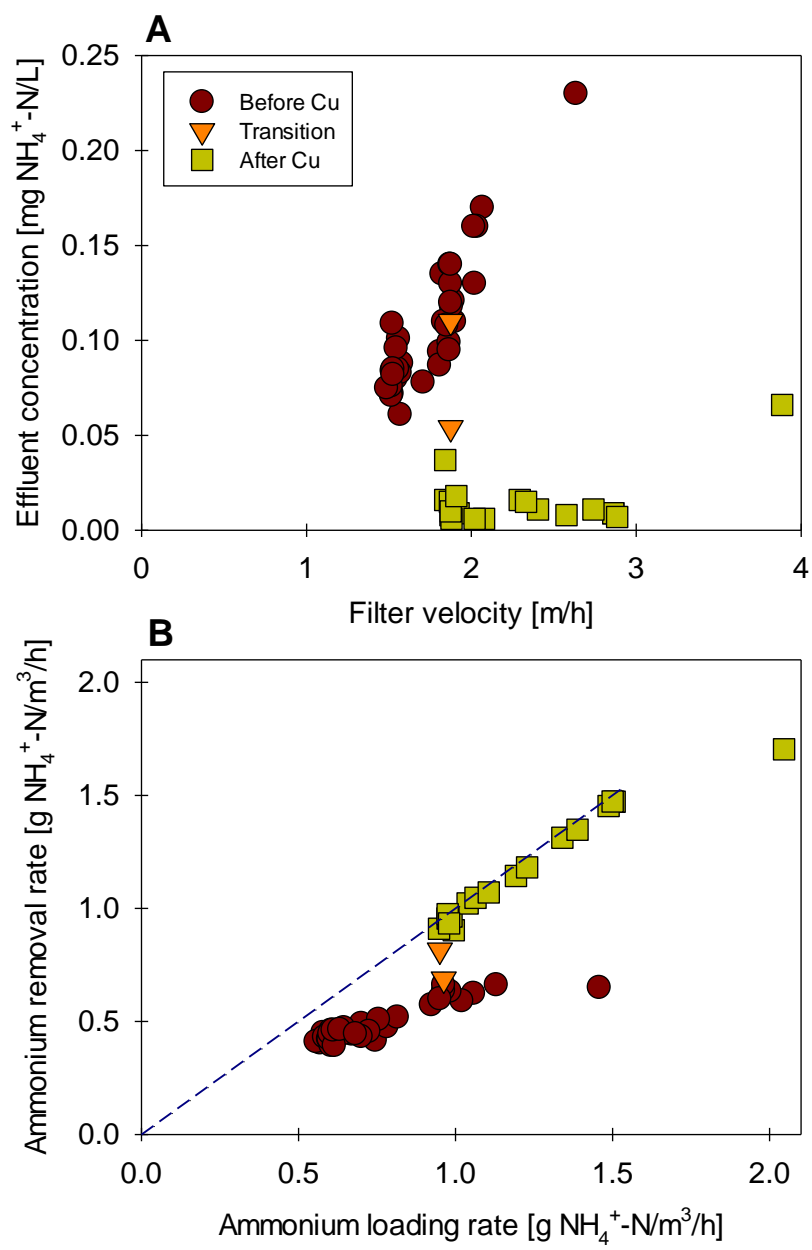

Figure 5: Effect of copper dosing on ammonium removal at increased loading rates (Holmehave DWTP). A: Ammonium effluent concentrations for different filter velocities. B: Volumetric ammonium removal rates (ARR) vs. volumetric ammonium loading rates (ALR). Different symbols depict three phases in relation to copper dosing. 

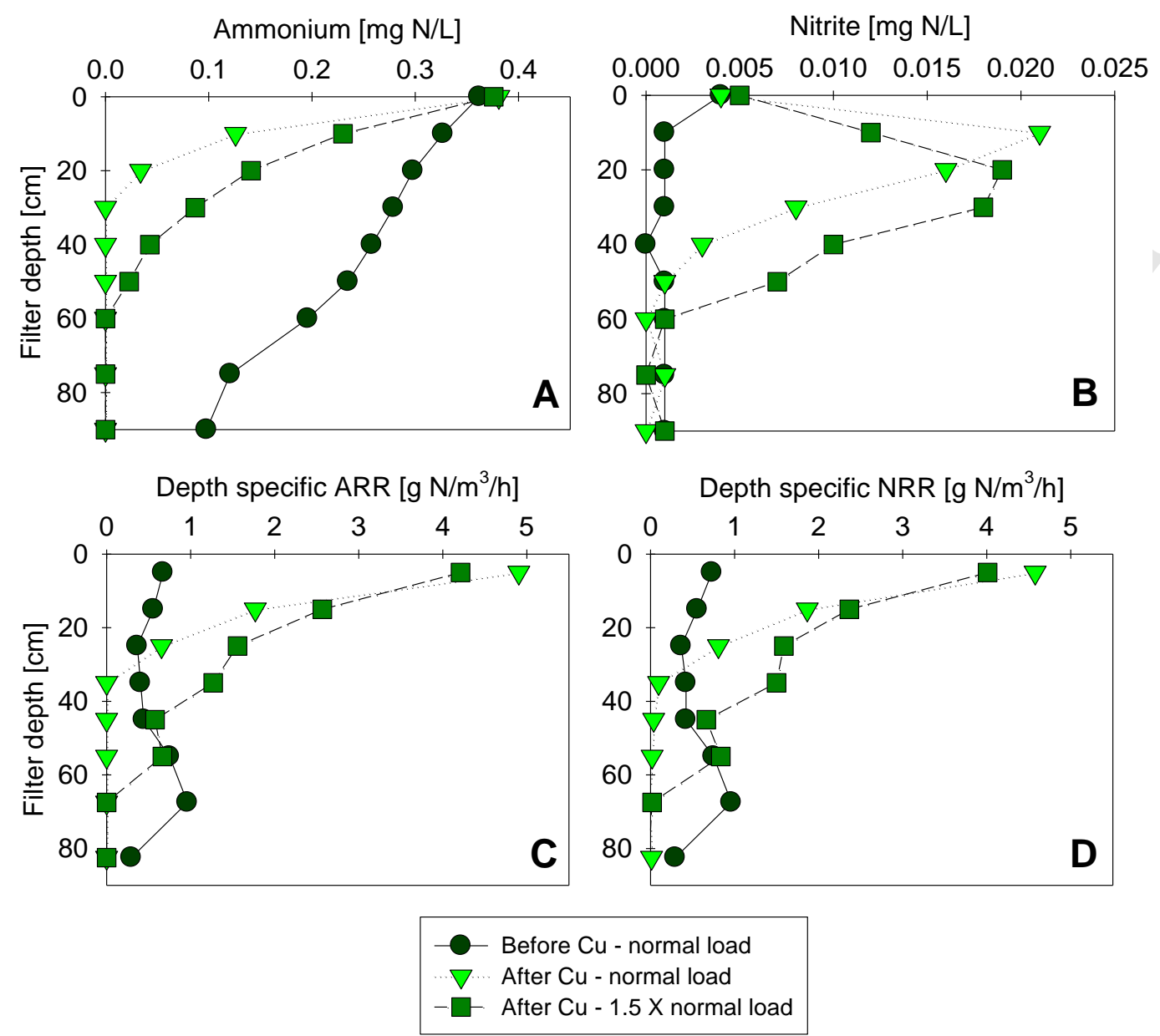

Figure 6: Effect of dosing on ammonium and nitrite removal over filter depth, at normal and increased ammonium loading rates (Holmehave DWTP). A: Ammonium, B: nitrite concentrations, C: depth specific ammonium removal rate, and D: depth specific nitrite removal rate, before and after copper dosing at a filter velocity of $1.92 \mathrm{~m} / \mathrm{h}$, and after copper dosing with increased loading rate at $2.88 \mathrm{~m} / \mathrm{h}$. 


\section{Highlights}

- At 10 out of 10 water works, copper dosing remediated incomplete nitrification

- It took only 3 weeks on average until complete ammonium removal was achieved

- Stimulation occurred despite variation in water chemistry, plant design and operation

- With dosing, filters completely nitrified even at increased ammonium loading rates

- Increased capacity buffered loading rate variations, thereby increasing robustness 